\title{
Making social capital produce for society: on the US financial crisis and capital credit
}

\author{
Xiaohe Lu
}

Published online: 11 June 2011

(C) Springer Science+Business Media B.V. 2011

\begin{abstract}
The global financial crisis, triggered by the subprime mortgage crisis in the USA, raises an important issue-namely, private production without the control of private property. The credit system has concentrated increasingly large social assets into the hands of financial institutions governed by a few people. This paper argues that the use of social capital for private production has played a key role in causing the subprime mortgage crisis. The credit and banking systems have abolished the private nature of capital and have instead provided a basis for organizing and implementing social production. However, these systems have not "overcome the antithesis between the character of wealth as social and as private." Therefore, it behooves us to explore what we can learn from the US financial crisis concerning how best to protect social interests, i.e., how to make the social capital produce for society.
\end{abstract}

Keywords Social capital · Financial crisis · Capital credit · Fictitious production of surplus value $\cdot$ Business ethics

The world seems to be moving out of the shadow of the financial and economic crisis triggered by the subprime mortgage debacles, but the underlying forces that caused the crisis have not yet been addressed and are worth probing. The author believes that the use of social property for private production has significantly contributed to the crisis. As a powerful means for concentration of capital, the credit system has been concentrating increasingly large social assets into the hands of financial institutions controlled by a small number of people. Although the credit system has formed the basis for the stock company and financial institutions, making

$\mathrm{X} . \mathrm{Lu}(\square)$

Center for Business Ethics, Shanghai Academy of Social Sciences, 1610 West Zhongshan Road,

Shanghai 200233, People's Republic of China

e-mail: 1xh@sass.org.cn

X. Lu

e-mail: zionlu@online.sh.cn 
them "a transitional phase of a new mode of production in terms of the functions of organization and implementation of social production" (Marx 2004, p 495), stock institutions "haven't overcome the antithesis between the character of wealth as social and as private" (Marx 2004, p 495). Therefore, it behooves us to explore what we can learn from the US financial crisis concerning how best to protect social interests, i.e., how to make the social capital produce for society at large. This paper is divided into four parts: (1) credit and the keepers of social capital, (2) private production without the control of private property, (3) the fictitious production of surplus value, and (4) making social capital produce for society as a whole.

\section{Credit and the keepers of social capital}

How much has the world, including the USA, lost during the current financial crisis? According to preliminary estimates, during the first 6 months in 2008, the stock markets worldwide erased $\$ 25-30$ trillion in wealth or $38 \%$ of the value of the world's companies (Beams 2008). Within the USA alone, according to "The Financial Crisis Inquiry Report" by the Financial Crisis Inquiry Commission (FCIC), "Seventeen trillion dallars in household wealth evaporated within 21 months" (FCIC 2011, p 389). ${ }^{1}$ This estimate does not include the amount the retirement accounts and life savings swept away (FCIC 2011, p 389) ${ }^{2}$ and the US government spent on the initial bailout of the banks. The US financial and banking bailout amounts to a staggering \$7.76 trillion, nine times the total US war expenditure to date in Afghanistan and Iraq, equivalent to $\$ 24,000$ per American (Pittman and Ivry 2008).

The value of US subprime mortgages was estimated at \$1.3 trillion as of March 2007 (see Associated Press 2007), with over 7.5 million first-lien subprime mortgages outstanding (Bernanke 2007a). So how did the crisis evolve into one that turned trillions of dollars of value into ashes worldwide and resulted in an economic crisis that pulled the real economy into an extended recession? I believe that this development was related, from the very beginning, to the crucial role played by credit in capitalist production and to the great power enjoyed by the credit administrators who occupied that role. It can be said that all wealth, past and the present, has been accumulated through credit. To a large extent, this wealth has also been extended in the form of credit. What has been erased or evaporated is monetary wealth in the form of credit. Therefore, it is necessary for us to start with a discussion of credit.

What is credit? I use Marx's definition. He argues that credit is a set of payment claims based on the function of natural money as a means of payment (zahlungsanspruch) (Marx 2004, pp 450, 531, 575, and 584). Once credit has appeared, "[c]ommodities are sold not only for money, but also on the basis of a written promise to pay for them at a certain date" (Marx 2004, p 450). Such credit can be put under the general head of bills of exchange. In view of this change, "The original general formula of capital, $\mathrm{M}-\mathrm{C}-\mathrm{M}^{\prime \prime}$ " (Marx 2004, $\mathrm{p} 181$ ) (that is, moneycommodities-money with an increment) is changed to $\mathrm{M}-\mathrm{C}-\mathrm{B}$, wherein $\mathrm{M}^{\prime}$ is

\footnotetext{
${ }^{1}$ See also p. 391 of the report "As a point of reference, GDP in 2008 was \$14.4 trillion."

${ }^{2}$ See p. 393 of the report: "By one calculation, assets in retirement accounts such as 401(k)s lost \$2.8 trillion, or about a third of their value, between September 2007 and December 2008.”
} 
substituted by $\mathrm{B}^{\prime}$ (bills of exchange with an increment). That is to say, now commodities are sold for more bills of exchange. If $\mathrm{B}^{\prime}$ (as additional payment claims) can be invested in extended reproduction as additional capital and does not need to be converted into money but can be realized directly through transfers and promissory notes or bills of exchange, then this formula $\mathrm{M}-\mathrm{C}-\mathrm{B}^{\prime}$ can be converted into $\mathrm{B}-\mathrm{C}-\mathrm{B}^{\prime}$.

In real economic exchanges, as long as these certificates/payment claims in fact balance debts and claims, they absolutely perform the payment function of money. There is, therefore, no need to translate them into money. The important role of credit in capitalist production was not recognized by people at the outset. As Marx pointed out: "[W]ith capitalist production, an altogether new force, the credit system comes into play, which in its first stages furtively creeps in as the humble assistant of accumulation, drawing into the hands of individual or associated capitalists, by invisible threads, the money resources which lie scattered, over the surface of society, in larger or smaller amounts; but it soon becomes a new and terrible weapon in the battle of competition and is finally transformed into an enormous social mechanism for the centralization of capital" (Marx 2004, p 722). During the process of capital accumulation, $\mathrm{M}$ in the $\mathrm{M}-\mathrm{C}-\mathrm{M}^{\prime}$ formula is not limited to slow accumulation, but can be enlarged through centralization. As Marx notes, "The world would still be without railways if it had had to wait until accumulation had got a few individual capitalists far enough along to be adequate for the construction of a railway. Centralization, on the contrary, accomplished this in the twinkling of an eye, by means of joint-stock companies" (Marx 2004, p 724). The "masses of capital fused together overnight by centralization reproduce and multiply as the others do, only more rapidly, thereby becoming new and powerful levers in social accumulation" (Marx 2004, p 724).

Credit not only facilitates capital accumulation, but also promotes equalization of profit, reduces the cost of money circulation, increases the circulation of commodities and the speed of metamorphosis in each stage of capital forms, and provides a foundation for new forms of social organization of capital in the form of stock companies. Thereby, "capital, which in itself rests on a social mode of production and presupposes a social concentration of means of production and laborpower, is... directly endowed with the form of social capital (Marx 2004, p 494) ${ }^{3}$ (capital of directly associated individuals) as distinct from private capital" (Marx 2004, pp 494-495). In addition, credit separates the managerial functions of capital from its ownership and separates labor from ownership of the means of production and surplus labor, thus leading to a transitional phase-the transformation of a new mode of production (Marx 2004, pp 490-498).

It is particularly noteworthy that credit concentrates social capital within financial institutions, enabling bankers, who act as money dealers and who have emerged as middlemen between lenders and borrowers of money capital, to become general managers of social capital and dominators of social labor. Because $\mathrm{M}-\mathrm{C}-\mathrm{M}^{\prime}$ has increasingly taken the form of $\mathrm{M}-\mathrm{C}-\mathrm{B}^{\prime}$ or even $\mathrm{B}-\mathrm{C}-\mathrm{B}^{\prime}$ (bills of exchangecommodities-bills of exchange'), borrowing and lending operations in the money

\footnotetext{
3 "Social capital" here does not mean "trust" as what F. Fukuyama uses, but means "capital directly associate with individuals".
} 
trade have developed as special functions for traders specializing in bills of exchange. Bankers now deal in credit itself in the form of discounted bills of exchange, direct loans based on personal credit, loans using various documents to prove ownership of commodities used as collateral, and bank overdrafts. Various forms of credit (e.g., bonds, securities, shares, and bills of exchange) can be considered mere symbols of credit insofar as their role is make all payment claims transferable. Dealing in credit or payment claims is a way to concentrate vast social capital into financial institutions, thus into the hands of the managers of these institutions.

What is managed by banks and financial institutions is moneyed capital, which in the form of lending capital or interest-bearing capital, assumes the formula $\mathrm{M}-\mathrm{M}^{\prime}$. Money in the formula $\mathrm{M}-\mathrm{C}-\mathrm{M}^{\prime}$ is thus reduced to its two extremes $\mathrm{M}-\mathrm{M}^{\prime}$, in which $\mathrm{M}^{\prime}=\mathrm{M}+\Delta \mathrm{M}$ (i.e., money creating more money). The process of production, $\mathrm{M}-\mathrm{C}$, and the process of circulation, $\mathrm{C}-\mathrm{M}^{\prime}$, which both operate as intervening processes, are omitted. In this way, Marx argues, "Capital appears as a mysterious and selfcreating source of interest - the source of its own increase" (Marx 2004, p 441). In other words, "It becomes a property of money to generate value and yield interest, much as it is an attribute of pear-trees to bear pears" (Marx 2004, p 441). While interest is only a portion of the profit (i.e., of the surplus value), it appears now, on the contrary, as the typical product of capital. "The product of past labor, the past labor itself, is here pregnant in itself with a portion of present or future living surplus labor. We know, however, that in reality the preservation, and to that extent also the reproduction of the value of products of past labor, is only the result of contact with living labor" (Marx 2004, p 449).

This sort of distorted and compressed understanding of the interest-bearing capital and its credit manifestation is strengthened by the uncertainties of credit itself. According to J. W. Gilbert, the author of The History and Principle of Banking, "Whatever gives facilities to trade gives facilities to speculation." ${ }^{4}$ In the case of credit, (1) the same payment claim (e.g., £1,000) is transferable and so, "[b]y a succession of transfers, [the claim is able to] multiply itself into a sum of deposits absolutely indefinite... Unless a run on the banks be made, the same $£ 1,000$ would, if sent back upon its travels, cancel with the same facility a sum equally indefinite." and (2) due to the development of the productive power of labor, and, thus, of production on a large scale, the markets expand and become more distant from the place of production, therefore, credits must be prolonged. Because buying and selling behavior can be separated from each other for a long time, these uncertain elements become the foundation of speculation. (3) Enticingly high profits have led to far more extensive operations than justified by the available liquid resources. When it is easier to obtain advances on unsold commodities, or when it is easier and cheaper to obtain credit, then such loans will be increasingly offered, thus, leading to "far more extensive operations than justified by the available liquid resources" (Marx 2004, p 458) and to overspeculation on these operations. (4) All securities represent nothing more than accumulated claims, or legal titles, to future production. Accumulation of money capital is nothing more, in the main, than an accumulation

\footnotetext{
${ }^{4}$ J. W. Gilbert, The History and Principle of Banking, London, 1834, quoted in Marx (2004, p 458).

5 The Currency Theory Reviewed, London, 1845; quoted from Marx (2004, p 457).
} 
of these claims on production, an accumulation of the market price, the illusory capital value of these claims. Therefore, with the development of interest-bearing capital and the credit system, all capital seems to have doubled, and sometimes even increased many times over. The largest portion of the venture is purely virtual (Marx 2004, p 533). Marx makes this point when quoting Leatham's observation on financed bills of exchange: "It is impossible to decide what part arises out of bonafide transactions, such as actual bargain and sale, or what part is fictitious and mere accommodation paper, that is, where one bill of exchange is drawn to take up another running, in order to raise fictitious capital, by creating so much currency. In times of abundance and cheap money, this I know reaches an enormous amount" (Marx 2004, p 451). In the US financial crisis, the so-called mortgage-based securities (MBS) and collateralized debt obligations (CDOs) are financing bills of exchange in nature and have been creating such fictitious capital.

In this way, the managers of social capital (by means of an upside-down formula of interest-bearing capital and by means of the speculative possibilities afforded by credit) have brought about "private production without the control of private property."

\section{Private production without the control of private property}

Seen from the perspective of the financial crisis triggered by the American subprime crisis, the managers of social capital engaged in, according to Marx, "private production without the control of private property."

Discussing how the credit system has gradually transformed capitalist enterprises into capitalist stock companies, Marx observed, "This is the abolition of the capitalist mode of production within the capitalist mode of production itself, and hence a self-dissolving contradiction" (Marx 2004, p 498). In other words, the social means of production is no longer private property, yet the social means still present themselves as if they were possessed by a handful of people and thus producing for the interest of the minority. This type of transformation into a stock company " $[\mathrm{h}]$ asn't overcome the antithesis between the character of wealth as social and as private wealth, but instead only developed such antithesis in a new form" (Marx 2004, pp 498-499) This contradiction manifests itself clearly as a pure, transitional phase to a new production pattern and as a new phenomenon as well. Marx highlights a striking manifestation of this contradiction: "It reproduces a new financial aristocracy, a new variety of parasites in the shape of promoters, speculators and simply nominal directors; a whole system of swindling and cheating by means of corporation promotion, stock issuance, and stock speculation. It is private production without the control of private property" (Marx 2004, p 497).

Why does a contradiction of this type of transitional phase manifest itself prominently in the form of credit speculation and fraud? The answer is that the social capital, which exists in the form of bills of exchange, is concentrated in the hands of a few people through credit and is moved and transferred as the result of pure gambling on bourses. Credit thus "lends the [holders of social capital] increasingly the aspect of pure adventurers" (Marx 2004, p 498). During this transitional phase, the stock company, while directly adopting the form of social capital and being 
exempt from the control by private property, reproduces a new type of financial aristocracy, which is able to pursue personal interests by operating and trading social capital by way of a whole set of speculative and swindler activities. Social capital thus still produces for individuals, a fact noted by Marx who observed that "all credit in general, is exploited by [these adventurers] as their private capital" (Marx 2004, p 541). Marx was remarkably prescient in noting the existence of a kind of private production without the control of private property, for such production is precisely what today's Wall Street financial aristocracy has engaged in by way of a whole range of speculative and swindling activities.

American bankers who made mortgage loans, these managers of the social assets, thought only of how to make money for themselves and how to seek personal gain by taking advantage of social capital. They did not stop to consider how they were putting social capital at risk. Commercial banks, along with insurance institutions, rating agencies and investment banks, created a production line for the securitization of mortgage loans, a kind of factory for financial derivatives to sell as the raw material for financial derivatives and as securities to be packaged by brokers, lenders and investment banks. Such private production through the use of the social capital is characterized by five aspects: (1) Home-buying borrowers not being required to provide any borrower credentials or even to make a $2 \%$ minimum down payment, so "an eye-popping $43 \%$ of first-time home buyers purchased their homes with no-money-down loans" (Knox 2006). (2) Large quantities of loans being granted to highly risky borrowers (especially the so-called "no income, no job and no assets" borrowers sometimes dubbed NINJNA ${ }^{6}$ ) who were encouraged to fetch rice with an empty bag (some of these borrowers themselves wondered why they were able to get such huge loans given that they did not have good credit records). ${ }^{7}$ (3) Various marketing vehicles, some of which were fraudulent, being employed to promote the predatory adjustable-rate mortgage (ARM), which artificially reduced the initial repayment amount, allowing borrowers to pay only interest, but which, after a time, adjusted to force the borrower to pay a much higher sum of interest and principal. When Greenspan raised the interest rate in 2004, those borrowers with interest-only ARMs found themselves unable to make the ever increasing payments. The risk was therefore transferred back to the lenders, while the loan brokers not only received large commissions but also plundered the interest already paid by the borrowers. Among the Americans who took out subprime mortgage loans, 80\% were granted ARMs (Dodd 2007). There were $\$ 265$ billion in subprime loans which, after adjustment, averaged a 12\% monthly interest rate (Associated Press 2007). (4) Insurance and rating standards for mortgage loans being adjusted downward in a dramatic fashion. According to recent investigations in 2004, about $41 \%$ mortgage loans were automatically packaged into securities and sold directly to investors, without any vetting. This percentage rose to 55\% in 2005 and $61 \%$ in 2006 (Brooks and Simon 2007). (5) Investment banks being tempted to blend subprime loans with other mortgage loans. These banks then securitized the blended loans and sold them. These securities were assessed and rated using a rating model inconsistent with the

\footnotetext{
${ }^{6}$ USA Today, "Risky-mortgage meltdown was predictable, preventable," August 10, 2007.

${ }^{7}$ For example, Clarence Nathan who had no formal job said: "I don't know why the bank did it. I'm serious ... 540 thousand dollars to a person with bad credit." Cf., "Giant Pool of Money", p. 3.
} 
real risks to investors worldwide. Many received an AAA credit rating, which implied that they were as secure as US Treasury bonds. The New York-based WMC regional housing mortgage loans broker Glen Pizzolorusso later confessed that he pocketed 75 and 100 grand in commission a month by making very large loans to very poor people with bad credit (This American Life 2008, p 9). As riskier loans required ever higher interest rates, he focused on peddling housing mortgage loans to NINJNAs.

For the same reason, Wall Street investment banks added ever more high-risk subprime loans to the mix, rather like those crooked managers at China's Sanlu Milk Products Company who added melamine to milk to improve its protein content and to maximize their profits. As these business transactions brought plentiful revenues to banks and investment banks, allowing them to get a good profit from every loan contract sold, banking institutions kept on pressing their credit brokers to ever more of these types of mortgage loans. Some brokers even went door to door, peddling to their poor neighbors. A New Jersey-based consultant Kerry Campbell commented that, since one loan contract could bring in $\$ 18,500$, these brokers had 18,000 reasons to forge mortgage supporting documents for NINJNAs and to entice these borrowers into homes they could ill afford to buy (This American Life 2008, p 18).

By 2007, the home loan securities market value rose to $\$ 6$ trillion, becoming the largest part of the US bond market. The US bond market was estimated at \$27 trillion, which exceeded the total value of US Treasury bonds (Beams 2008). Excessive private production by US banks and financial institutions made the working class city of Cleveland the US subprime capital. The subsequent wave of contractual breaches and buybacks had a destructive effect on the whole city and its environs. By late 2007, one tenth of Cleveland's dwellings were under foreclosure by German Trust Bank, the city's largest creditor (see BBC NEWS 2007).

Traditionally, American banks receive deposits and then lend in the "3-6-3" model, i.e., bankers pay 3\% interest on deposits, lend at $6 \%$ interest, and go to a golf course at 3:00 p.m. Bankers were able to go golfing only if they stuck to their traditional "originate-and-hold" model. This model exhibits an obvious reasonableness, because banks, as the manager of social deposits have the duty to act as keepers and trustees of these deposits. As managers of social capital, banks have the obligation to make it appreciate. That is, they need to regard social capital as money capital and transfer it to the hands of people who know how to use it and how to maximize the use value of capital in order to create more surplus value. Banks' earned interest on deposits gets paid out of this surplus value.

The originate-and-hold model reflects the nature of banks as lenders of capital. Origination is only the vehicle whereas holding is the aim, basis and premise of origination. Without holding and more holding, there would be no originating and more originating. This original model of banking also accords with the formula for lending capital: $\mathrm{M}-\mathrm{M}-\mathrm{C}-\mathrm{M}^{\prime}-\mathrm{M}^{\prime}$, i.e., the release of the right to pay from $\mathrm{M}-\mathrm{M}$ aims at a payback from out of the created surplus value of $\mathrm{M}^{\prime}-\mathrm{M}^{\prime}$. As such, banks' sticking to a policy of "holding" and "originating" means that they themselves must take on the risks of making loans and that it falls to them to set curbs on lending to insure that the second $M$ transferred to the industrial capital will flow back with the first $\mathrm{M}^{\prime}$ and that banks will be paid back from the second $\mathrm{M}^{\prime}$. 
The originate-and-hold model historically resulted in banks being regarded as moral and religious institutions. "How often has the fear of being seen by the watchful and reproving eye of his banker deterred the young merchant from joining the company of riotous and extravagant friends? What has been his anxiety to stand well in the estimation of his banker? Has not the frown of his banker been of more influence with him than the jeers and discouragements of his friends?" Because any dishonesty on the borrower's part would create suspicions and lead his banker to restrict or even cancel his loan, the banker's advice was of greater value to the borrower than that of a priest (Marx 2004, p 618).

Yet, this originate-and-hold model has been replaced with an "originate-anddistribute" model. In the case of the subprime mortgage loans, this new model has manifested itself as the production line for housing mortgage lending securitization. Now, the bank no longer needs to hold onto its loans. Instead, it can sell these loans to replenish its funding pool, which means that the bank, in turn, can originate more loans and thus earn more transaction fees without being worried about whether the loans will ever be repaid. In effect, the banks have become middlemen between the borrowers and the buyers of the loans with one hand originating the loan and the other handing the IOU out to other parties.

As far as the bank itself is concerned, it has accomplished its job as the middleman and received its due commission. The bank has little or nothing to do with borrowers' credit status or the credit quality of the loans extended. Seen from the perspective of the housing mortgage lending securitization production line, the borrower remains the home buyer. The lender is still, formally speaking, the bank who made the loan to the home buyer. But, in reality, the lender has silently morphed into those banks or funds that bought the MBSs and CDOs. In the final analysis, the lenders are those people who live in far-flung countries and who have bought and sold stocks and invested in funds. Managers and depositors with foreign banks never imagined that investment banks and other types of banking institutions in the USA would operate merely as middlemen and base the safety of their assets on the debt-servicing ability of borrowers who cannot even afford the space in which to place a urinal.

From the above analysis, we can see that those entrusted with social assets used various financial derivatives and a whole set of speculative and fraudulent operations to pursue personal gains at the expense of those who had trusted them with social assets. Capital managers evolved into financial-draft middlemen who marketed risky products, transferred risks, and obtained huge private gains without assuming the responsibilities of trustees. Instead, they transferred costs and risks to subprime borrowers. When the latter defaulted, the loss of social assets was assumed by the general public and international investors. ${ }^{8}$

Some people have observed that the subprime crisis had three catalysts: the money from the private sector, and banks coming into the mortgage-backed securities market, and the predatory practice of mortgage brokers in originating loans,

\footnotetext{
${ }^{8}$ Statistical data show that the amount of MBS sold by banks in 2007 was three times that in 1996, up to $\$ 7.3$ trillion while securitized stocks based on subprime mortgages also surged to $75 \%$ in 2006 from $54 \%$ in 2001. Security exposure involving subprime risk, to the tune of approximately $\$ 25$ trillion, had been transferred to third party investors.
} 
especially the ARM (see Wikipedia, the free encyclopedia). However, liquidity problems and financial fraud are nothing new. So, why did these two catalysts trigger the subprime crisis, and what are the more fundamental causes of the crisis?

\section{Production of fictitious surplus value}

There have been a number of explanations as to why the financial crisis took place. Some analysts blame Alan Greenspan for raising the interest rate. Others believe greed is the root cause, as is indicated by a US article that said, "Don't attribute the financial crisis only to the greed of Wall Street; in fact every American is greedy and should be held responsible for the meltdown." Still others assert the crisis resulted from the consumer culture, which led to overconsumption.

Another group contends that the formula of Dr. Li Xianglin caused things to go south, this formula allowed American financial institutions boldly to sell a variety of new securities and financial products and thus to expand the financial market to an unheard of level. Since Dr Li himself went back to China before the financial crisis broke, this view has engendered a "China Conspiracy Theory." Given that American administrations from Roosevelt and Reagan to Clinton and Bush pushed home ownership, another class of critics argues that this political fixation led Wall Street to devise products that allowed Americans to buy homes. Given that many of these home mortgages have ended up being paid for by people in other countries, this point of view can be termed the "US Conspiracy Theory."

A relatively authoritative official view attributes the crisis to irresponsible behavior. Reuters reported on September 25, 2009 that the "G20 [declared] victory over crisis: the G20 vowed not to return to the 'imprudent behavior' blamed for triggering the financial crisis... We hope to see an economic development without prosperity and recession occurring in turn cyclically and a market that fosters a sense of responsibility rather than imprudent behaviors" (Reuters 2009). So is the financial crisis caused by "imprudent behaviors"? Is the G20 hope or pledge really achievable? Or more specifically, why were such "imprudent behaviors" able to prevail? Why were those keepers of social capital no longer able or willing to follow the traditional "lend-hold" model?

I personally believe all the above factors contributed to the crisis, including the Bretton Woods Agreement, which decoupled gold from the US dollar and boosted the development of financial derivatives (see Beams 2008). ${ }^{9}$ The Gaussian copula function developed by $\mathrm{Dr} \mathrm{Li}$ Xianglin did provide a convenient tool for risk assessment of derivatives, and it did promote behavior not rooted in the reality of lending (see Pittman and Ivry 2008, p 18). These reasons are not the root causes, however. The root cause lies in fundamental capitalist contradictions.

These contradictions have led to the production of fictitious surplus value, which has caused, in turn, a further change in American capitalism's original fundamental contradictions. This change has produced a shift from the production of real surplus

\footnotetext{
9 "In 1972, the year after the demise of the Bretton Woods Agreement, a market in currency futures was launched on the Chicago Mercantile Exchange." "The currency futures contract was only one of many new financial derivatives that were to develop in the next period."
} 
value to the production of fictitious surplus value. In the process, credit has become not only a powerful means for capitalist production to surpass its own limitations, but also a highly effective tool allowing dishonesty to prevail. All the aforementioned reasons can be best understood in this context of fundamental contradictions.

Fictitious capital is also called imaginary capital. One example of imaginary capital is credit currency. Credit currency, in forms such as bonds, securities, shares, and bills of exchange, is just a payment claim. It is not paper currency, but is based on paper currency. It can be realized as real currency, but, as money capital or interest-bearing capital, it is imaginary and capable of bringing in surplus value. In short, credit currency is imaginary interest-bearing capital capable of bringing in interest.

In light of the relationship between credit and capitalism, the production of fictitious surplus value or fictitious profit pairs with excessive consumption or consumerism. For consumers, capitalism seeks to promote excessive consumption by extending credit and uses credit as a lever to accelerate the conversion from commodity to currency. Capitalists get back their investment only by selling their products, which include the original investment plus any surplus value. By extending credit, capitalists can accelerate the realization of these gains.

Capital, however, manifests itself as excessive financing and leaves out the real economy. According to a study by Adam Davidson, an international business reporter, global idle capital prior to 2000 amounted to $\$ 36$ trillion and earned a fixed return for its owners who bought national or public debt and bonds issued by local governments. Thanks to the advancement of multinational corporations and emerging market-oriented economies, this figure doubled to $\$ 70$ trillion in the years after 2000. It is now roughly equal to the total of worldwide deposits or savings. It was at precisely this critical juncture (when the world was experiencing excessive capital liquidity) that Greenspan lowered the benchmark interest rate for federal funds from $6.5 \%$ to $1.0 \%$ through 13 reductions during the period 2000 to 2003 (This American Life 2008, pp 3-5). But the drive of capital to pursue profits did not change, so the giant army of money capital faced the problem of how to realize its return on investment. A decline in profit, Marx once said, always makes capitalists very nervous.

The same problem was worrying those managers who were in charge of the $\$ 70$ trillion (This American Life 2008, p 4). How could bankers link this huge quantity of liquidity to investors' preferred investments-housing-backed mortgage loans? This was the real problem considered by the likes of Mike Francis, a managing director in the housing-backed mortgage loan transaction department of the investment bank Morgan Stanley. Wall Street talents focused on using housingbacked mortgage loan to lure the $\$ 70$ trillion into their hands. Investors were willing to do almost anything to avoid having to accept the miserable $1 \%$ interest rate Greenspan was giving them. Meanwhile, American home buyers were only too happy to borrow at 5-9\% interest rates. The problem the investment banks faced was that global investors did not want to get involved in offering mortgage loans to home-buying individuals. These investors did not want to have to think about risks posed by, for example, borrowers' health or marriage problems. Wall Street bankers decided, therefore, to "give the global liquidity all the benefits, but none of the troubles or risks" (This American Life 2008, p 5). 
They designed a whole business chain. At one end were individuals who, though poor, needed a home. There were many such people, especially ethnic minorities and immigrants. These folks could manage to get mortgage loans from brokers who sold the mortgage loans to small banks. These banks, in turn, did not hold on to the loans but sold them one to three months later to Wall Street investment bank traders. These traders packaged thousands of these loans into securities known as MBS. These MBS were favored by global investors, especially institutional investors (This American Life 2008, pp 5-6). The investment bankers' after-the-fact confessions show that, given the fictitious consumption power created by the subprime loans, fictitious capital directly adopted the $\mathrm{M}-\mathrm{M}^{\prime}$ formula. More precisely, they adopted the $\mathrm{B}-\mathrm{B}^{\prime}$ method, making money by making money capital directly produce interest.

$\mathrm{B}-\mathrm{B}^{\prime}$ is the fictitious form of $\mathrm{M}-\mathrm{M}^{\prime}$. The interest-bearing capital formula $\mathrm{M}-\mathrm{M}^{\prime}$ omits the commodity process $\mathrm{C}$, though the actual formula should be $\mathrm{M}-\mathrm{C}-\mathrm{M}^{\prime}$. The production of American subprime-loan derivatives depended not on $\mathrm{M}-\mathrm{C}-\mathrm{M}^{\prime}$, not even on $\mathrm{M}-\mathrm{M}^{\prime}$, but on $\mathrm{B}-\mathrm{B}^{\prime}$. That is to say, the purveyors of these loans did not return to the process of production. Rather the purveying work without the commodity production process $\mathrm{C}$, using only a circulation process running through the offices of banks and investment banks. So the creation of derivatives was, first of all, purely a reversed and abbreviated formula of interest-bearing capital. Second, the creation was a production of fictitious capital, or more precisely, a production of fictitious surplus value of fictitious capital. In appearance, the creation had products and a $\mathrm{C}$ process, but its products were financial derivatives, and its process was producing financial derivatives. The added value part of $\mathrm{C}^{\prime}$ and $\mathrm{M}^{\prime}$, or the added value in surplus value, was also fictitious, so its real formula was only $\mathrm{B}-\mathrm{B}^{\prime}$ - i.e., using credit money directly to produce more credit money.

Insofar as credit money represents natural money's right to be paid, accumulating credit money equates to accumulating payment claims. As such, credit money is the claim to realize payment of added value in money. But seen from the perspective of the whole capitalist production, the purveyors of subprime derivatives are not entitled to acquire the interest they claim. They are not entitled to receive the ownership compensation of the social capital they employ, because, although loan capital doesn't create surplus value, it contributes to the shortening of the processes in which capital transforms from one form to another. But the basis for the interest associated with subprime derivatives is at most only the cost of producing them, or the cost of circulation, and has nothing to do with any production aiming at realizing surplus value. In other words, money capital or interest-bearing capital, when applied to derivatives, does not even bother to enter into the real productive process whereby surplus value is created but is merely the simplified form $\mathrm{B}-\mathrm{B}^{\prime}$, the credit symbol of the abbreviated money formula $\mathrm{M}-\mathrm{M}^{\prime}$. Money capital is akin to a hen that does not lay an egg or to a paper hen that dreams of laying an egg. Although its egg is entirely imaginary, this hen enjoys the right to get a real egg. The money used by investors and fund managers around the world competed to buy this imaginary hen is the real accumulation of savings and investments by individuals. So for the purveyors of the derivatives, the added value in surplus value to which they competed becomes a matter of distribution. How could they strike the right tone or adopt the right style to persuade people to give up their real savings in order that money can be transferred into the bankers' hands? This kind of production is no 
longer wealth creation, but rather a redistribution of the wealth already created. What has been altered is only the distribution of capital and the quantitative combination of all the components of social capital.

One reason that this kind of production of fictitious surplus value flourishes in the USA is that America is already well into the credit economy stage. According to Marx's characterization of the differences among money, paper money, and credit money, a credit economy is arguably the advanced stage of a money-based economy. If paper money can be said to be the payment warrant of metal money, then credit money is the warrant of the warrant of metal money. The advancement of the latter warrant is due to the former two means of circulation failing to meet totally industry and commerce's ever-growing need for greater and faster circulation. Compared with the first two forms of money, credit money exhibits more resilience and provides greater convenience in time and space. With credit, for example, lending, borrowing, and paying can be done without metal money or paper money having to be carried around by people. As Marx put it, "[Credit-money proper does] not rest upon the circulation of money, be it metallic or government-issued paper money, but rather upon the circulation of bills of exchange" (Marx 2004, pp 450-451). But if credit money were to forget that it is itself the payment warrant of metal money and paper money and were to expand infinitely, then a danger would arise: "This enormous superstructure of bills of exchange rests (!) upon the base formed by the amount of bank-notes and gold, and when, by events, this base becomes too much narrowed, its solidity and very existence is endangered." 10

The danger is manifest in the statistics. The major Wall Street investment banks' ratio of equity to assets rose from 23 in 2004 to 30 in 2007. Investment bank Goldman Sachs, for example, had assets valued at only $\$ 40$ billion, but had equity worth $\$ 1.1$ trillion. This sort of danger is not merely a problem with the credit form of money. ${ }^{11}$ Whatever civilized form it takes, money can only acquire what is based on the real creation of surplus value. Hence, the production of fictitious surplus value could satisfy money capital in its pursuit of fictitious profit by offering an endless list of a variety of structured financial derivatives. Yet, in the final analysis, this production must acquire a real power to fuel consumption and serve as the basis for real wealth production. In the case of the USA, capital credit is increasingly used not to expand production-oriented capital, but used instead only in the financial market.

As a result, the problem lies not only with a handful of investment banks taking on an excessively large superstructure, but with the whole economy, which now exhibits symptoms of being overblown due to excessive financing. In 1981, "It is estimated that the US credit market was $168 \%$ of GDP. By 2007 , it was $350 \%$. Financial assets were five times larger than GDP in 1980, but over ten times as large in 2007"; and the "debt taken on by banks and other financial institutions rose from $63.8 \%$ of US GDP in 1997 to $113.8 \%$ in 2007" (see Beams 2008). What is especially

\footnotetext{
${ }^{10}$ W. Leatham, 1840. Letters on the Currency, quoted from Marx 2004, p. 618.

${ }^{11}$ Cf. also FCIC Report, in 2007, the five major investment banks "were operating with extraordinarily thin capital. By one measure, their leverage rations were as high as 40 to 1 , meaning for every $\$ 40$ in assets, there was only $\$ 1$ in capital to cover losses." "The kings of leverage were FANNIE Mae and Freddie Mac," by the end of 2007, Fannie's and Freddie's combined leverage ratio, including loans they owned and guaranteed, stood at 75 to 1. pp., xiv-xx.
} 
striking is that almost half of the debt in the US credit market is employed by the country's financial institutions. In other words, half of the $\$ 57$ trillion credit obligations created by the US financial institutions are exploited by these same institutions.

The use value of money capital works to bring in surplus value. To create surplus value, one has to return to the process of production whereby money capital converts into production capital. At that point, banking capital faces the same problem as industrial capital. Industrial capitalists regard those whom they employ as workers, but they regard those workers whom other capitalists employ as consumers who should be entitled to consume commodities to the largest possible extent. These capitalists, thus, imagine workers as "adequate demand". To obtain more profits, however, capitalists have to increase surplus labor or shorten necessary labor. As a result, capitalists will reduce their workers' salary, therefore, decrease their workers' demand or spending power. Capital always forgets and disregards limits to consumption. The result is overproduction. Capital only "brings to mind all these necessary elements of capital-based production" when a crisis erupts. ${ }^{12}$ The same can be said of credit capital or lending capital. Lending capital regards itself as interest-bearing capital but considers all other types of capital as production capital or industrial capital. In Marx's words, lending capital regards production capital as its laborer. Consequently, lending capital commits to expanding fictitious capital infinitely, which exacerbates the already declining average profit.

But if all money capital does not convert into production capital but remains as lending capital, then who will volunteer to create surplus value for lending capital? As a result, when the boundless pursuit of surplus value by interest-bearing capital cannot be realized by banking on production capital, it turns to the production of fictitious surplus value directly in order to satisfy its hunger for demand. Greedy brokers, the credit managers at small banks and the Wall Street purveyors of MBSs and CDOs at the upper end of the financial factory production chain have to be paid at the end of the day by those who took out the mortgage loans. But if those same households cannot afford to buy a toilet, how on earth can they meet this huge demand of fictitious capital? Hence, although credit can develop the potential of capital to the greatest extent and make capitalist production more resilient, credit has been unable to solve the living contradictions of capital disclosed by Marx.

While production of the fictitious surplus value is unable to solve the fundamental contradictions of capitalism, credit actually plays the role of a tertiary distributor. Credit redistributes and deprives capital of capital. Credit is the lever not only for overproduction and speculation, but also for capital buildup and depletion. According to research by Song Hongbing, the total US debt amounted to $\$ 57$ trillion by 2008 and continued to grow at an annual pace of $7-8 \%$ (when compounded), while the sustainable US GDP and national revenue grew at a rate of only $3 \%$. If this pace continues, the cost of US debt obligations will increase faster than US national revenue. By 2051, the total interest payments for all US debt obligations will surpass total US national revenue, which would mean the complete bankruptcy of the US economy. These debt obligations, it should be remembered, do not even include the more than $\$ 100$ trillion of hidden liabilities associated with

${ }^{12}$ Karl Marx, Manuscripts of Economics, Corpus of Marx and Engels, vol. 30, p 397. 
healthcare and social security funds. According to Song's calculations, the USA will never be able to pay back this level of debt (Song 2009, pp. 275-276). If his prediction is correct, I am afraid that the USA will have no choice but to continue attracting liquidity from abroad.

It is worth noting that Greenspan, from 2000 onward, chose to lower the interest rate, signaling that the USA and the American banks no longer wanted to borrow money and to incur interest costs. On the other hand, easy money and cheap credit encouraged the American people and businesses to engage in borrowing-based consumption and speculation, which expanded the bubble. Lowering the interest meant, in effect, that the government would no longer allow US consumers and industrial capital to work for international lending capital. Of course, if Greenspan's decision to lower the interest rate had really worked to drive away international liquidity, US banks and financial institutions that have relied on international liquidity for survival would have been in jeopardy. As one commentator observed, "If you are asked to grade today's market, the banking system is already bankrupt."13

Yet there is another possibility. Large inflows of idle money might continue on the condition that (1) there are still people who are ready to lend, a condition which can be met by a loose money policy and cheap credit; and (2) there are high interest rates offered by parties other than the already deeply indebted American government, banks and financial institutions. Whether Greenspan foresaw it or not, the managers of the giant army of flowing capital, which doubled after 2000, were ready to swallow the bait of the financial derivatives designed by the Wall Street talents to be attractive to these investors. In the short run, everyone seemed satisfied and liquidity kept coming in, creating the phenomenon Ben Bernanke thought was overlooked by Greenspan: International idle money actually kept pouring into the US credit market at an even greater rate despite the market's low interest rates (Bernanke 2007b).

The 2002-2004 low interest rate policy of the US combined with the inflow of funds provided US banks and financial institutions with adequate liquidity and allowed their managers to earn large sums. It also created cheap credit and fueled the ongoing expansion of the housing price and credit bubble. Then, from July 2004 to July 2006, the Federal Reserve raised the interest rate 17 times in a row, leading Fed Funds to jump from $1 \%$ to $5.25 \%$ (Federal Reserve Board 2010). As a result, the subprime bubble burst. Something on the order of \$25-30 trillion vaporized from the total army of flowing capital. The value of most MBSs and CDOs dropped by half with some becoming entirely worthless. Four major Wall Street investment banks went bust due to their greed. The losses included part of the interest payments made by subprime-loan borrowers. When discussing the British banks' efforts to use legislation to avoid paying what they owed in arrears on grain transactions, Marx argues that, during a crisis, this sort of fictitious money capital decreases a lot and the power of its owners to acquire money with fictitious capital diminishes as well. ${ }^{14}$ Since MBSs and CDOs are warrants of trust, the subprime crisis erased the power of these warrants to acquire money. The crisis undercut the position of banks, which had not successfully sold all of the warrants

\footnotetext{
13 "If you mark to market today, the banking system is bankrupt," Tobin said. "So what do you do? You try to keep it going as best you can."

${ }^{14}$ Karl Marx, Manuscripts of Economics, Corpus of Marx and Engels, vol. 30, p 559.
} 
they were holding. As the overblown portion of the liabilities was cleared away, debts and financial claims were brought back into balance.

Upon the outbreak of the financial crisis, Greenspan told Senator Christopher Dodd, "The current credit crisis will come to the end, and, as most of the increment in newly built homes is paid off, the housing prices fall will come to a stop and thus will bring the currently uncertain housing assets prices to a stable level which will serve as a bumper for all the housing mortgage loans, and most importantly as a bumper for mortgagebacked securities. No doubt, there will a great loss as the consequence of this crisis. But, after a time of protracted adjustment, the American economy and, more generally, the world economy will be able to be back in business" (The Economist 2007). Seen from the objective outcome of the crisis, the production of subprime derivatives was unable to replace the production of the real surplus value and to settle the contradictions between capital and labor and between production and value realization. Nor could it solve the problem of overcapitalization through real investments. However, the crisis (through the production of the fictitious surplus value, the depreciation of lending capital and the elimination of liabilities, and the loss of the payment claims based on the nonrecoverable mortgage loans) did rebalance the liabilities and the financial claims posed by derivatives. The crisis thus permitted industrial capital to get on with its job without distractions. In Greenspan's phrase, the adjustment enabled the American economy "to be back in business." To quote Marx, "The overproduction of capital is the excessive accumulation of capital. There would be absolute overproduction of capital as soon as additional capital for purposes of capitalist production $=0$. In any case, balancing can be restored only through capital, big or small, being laid aside, or even eliminated. As such, the capitalist production mode sets a limitation to itself, which is to develop the productivity of labor through a continuous revolution in the production method, i.e. the depreciation of capital, or at the cost of the productivity already created" (Marx 2004, pp 278-280).

\section{Making social capital produce for society}

Since the financial crisis began, academics have conducted numerous seminars, offering many explanations of and solutions to the crisis. The USA itself has taken multiple steps at the governmental level to address the crisis. These steps include a fiscal bailout, economic stimulus and new forms of financial supervision, including protections for consumers. The USA has also set limits on CEO compensation, imposed stricter requirements for bank capital adequacy, and expanded regulation of the shadow banking system and the production of derivatives while strengthening institutional safety and prevention measures at Federal Reserve banks. The Obama administration set up a task force to investigate fraudulent practices and to decide what legal actions, if any, to take against fraudsters in order to minimize the impact of the crisis and to prevent similar problems from recurring. ${ }^{15}$

\footnotetext{
15 In May 2009, the US Congress passed and the President signed the Fraud Enforcement and Recovery Act. (FERA). As part of the Act, the Financial Crisis Inquiry Commission was established to "examine the causes of the current financial and economic crisis in the United States" and was submitted its Final Report on 27 January 2011. This paper was presented to "2010 Shanghai International Conference on Business Ethics" on 29 October 2010.
} 
Discussion among US academics and people within the financial industry tends to favor a return to the more surefooted way of wealth production. Fareed Zakaria, the noted editor of Newsweek, believes the financial crisis will spur the American people as well as the US government to take steps to make ends meet. He has argued that Americans should place its best talent in the more value-oriented fields of managing businesses and in the fields of science and technology rather than in the finance sector (Zakaria 2008). General Electric CEO Jeffrey Immelt is convinced that US current account and budget deficits are unsustainable and that the US must regain her power to compete by developing more innovative products, cultivating a production work force, and exercising sound business leadership. National objectives, he contends, should be established in with respect to energy security and independence, the development of specific technologies, the increase in the number of manufacturing jobs, and the position of net-export nations (Charlie Rose 2009).

Marxists and socialist political parties have also weighed in. The Socialist Equality Party has argued that the subprime-crisis-led financial crunch was caused not by an incorrect monetary policy or by lax supervision but by the contradictions immanent within the capitalist system. The historical meaning of this crisis lies in the public understanding that productivity must be emancipated from the outdated irrational and destructive profit system. This party even goes so far as to put forward an international guideline for a World Socialist Revolution, calling for pulling "down the capitalist ruling class and develop[ing] a worldwide planned economy based on democratic decision making by world producers" so that people's lives will no longer be turned upside down and the future of their children will no longer be at the mercy of the market and the profiteering of a blind capitalism. ${ }^{16}$

In my opinion, this judgment about the origins of the crisis basically accords with Karl Marx's analysis of the fundamental contradictions of socialism, but these socialists lose sight of three important points. First, they disregard Marx's idea of "utilizing capital to do away with capital," which means that overcoming the contradictions of capital is premised upon a great advancement in productivity. This advancement can be achieved only by using the capitalist production mode. Second, they disregard Mark's view on the "transitional phase." Marx believed that credit not only plays the great role of a lever for capitalist overproduction and speculation in commerce, but at the same time brings about a transitional form involving a shift to a new production mode. Third, they disregard the characteristics of a stock company and thus fail to notice that today the people who run companies are not the nineteenth-century capitalists who had both ownership and managing power.

The problems within contemporary companies and contemporary economies cannot therefore be solved simply by taking over the rein from the hands of capitalists. From a global perspective, as long as the production process in which capital converts all of the use-value into exchange-value remains uncompleted; and as long as the concentration of aggregate social capital remains uncompleted, it is hard, if not impossible, to implement a planned world economy merely by political means. The actual capitalist contradictions, therefore, are in no way resolved simply by applying Marx's theory.

${ }^{16}$ Nick Beams 2008. 
I would argue that as long as globalization remains uncompleted, capital's historical mission also remains unfinished. The capitalist production mode remains alive. For capital to become more civilized in nature, we must, through the practice of business ethics, promote social interests and make social capital work for society. ${ }^{17}$ Marx's remark about the characteristics of the "transitional phase" should make us appreciate the fact that there exists private production without the control of private property. Thanks to credit, capital is now easier to concentrate globally than at any time in the past. As a form of credit capital (when placed in the hands of a few financial institutions and their managers) will likely evolve into a gambling and swindling system. As a result, the world economy will be more turbulent and volatile, and social capital, which is at the transitional point of a credit economy, will be more vulnerable. The nineteenth-century business crises that Marx studied had their impact limited to the UK, but today's US credit crisis spread far and wide. So there is a general feeling that such credit chilliness is a new phenomenon, a credit problem of proportions the world never saw in the past (This American Life 2008, p 20).

The US financial crisis demonstrates that the credit economy or the transitional phase of this new production mode into which the US has entered has brought to the fore the problem of private production without the control of private property. As capital evolves in a globalized way, a credit economy will increasingly pool social capital and global assets into the hands of a few financial institutions and managers. As social capital freely develops the useful part of capital's private nature and discards the useless remnant, the contradiction that used to exist between capitalists and workers will manifest itself increasingly between managers and the owners of social capital. The problem becomes one of how best to protect the interests of social capital's owners from predation by business executives. Given the nature of social capital, it is reasonable for us to expect that social capital should produce for society and emphasize the need to make key actors accountable.

Managers of social capital should take on the responsibility of producing for society. Managing the economy begins with managing financial capital. If government officials are the managers of public interests, then banks are the managers of social capital. In the developed credit economy phase, the question is whether banks should be managed on behalf of a minority or society as a whole. During the past 30 years, this problem has been repeatedly raised and addressed within the Western business ethics movement. It is precisely this problem that the US financial crisis once again forces us to heed.

Moreover, this problem faces primarily banks and other financial institutions rather than stock companies and public corporations for numerous reasons. First, social capital is highly concentrated in the hands of a small number of managers. Pressure from competition will increase this concentration on a global basis. In terms of property rights, the lenders and users of social capital are neither its owner nor its

\footnotetext{
${ }^{17}$ I should add that as early as in 2000, Alex Michalos has realized the serious risks involved in the "excessive growth of the world's financial economy relative to the world's real economy," and supported "Tobin taxes" as "one sort of policy instrument that will not only reduce the risk of financial crises but will also raise revenue on a global scale to press into service to solve global problems." It is worthy to note that one of the arguments he has raised for "Tobin taxes" is that "Provide opportunities for international cooperation focused on a type of globalized activity that would serve the public interest rather than merely the interests of private wealth holders." See Michalos and Alex 2000; also see Michalos and Alex 1997.
} 
producer, so social capital is not private. Yet the owners of this social capital are not easily located. The chain of dispersed individual assets and their commissioned agents is so long that the owners of social capital have no real control over this chain. By contrast, financial institutions' executives enjoy command of social capital while escaping accountability.

Second, banks and credit institutions are the most powerful tools whereby capital goes beyond its own bounds; at the same time, they are the most effective instruments from which a crisis may arise, for they allow for dishonesty. They possess the greatest capacity to engage in fraud and thus expose social capital and social stability to a higher order of risks. Third, as long as the capitalist production mode persists, interest-bearing capital will persist in one of its many forms. It will continue to function as the foundation of the credit system, thereby enabling managers of credit institutions and operators of interest-bearing capital to seek personal gain by using the credit power and interest-bearing power to personal advantage. The so-called "private production" refers to managers' ability to convert social capital and social credit into a source of personal enrichment. Fourth, these rewards, which go far beyond a manager's legal compensation, are not a slice of overhead expenses taken out of the interest paid as a return on capital. Rather, this enrichment is an unjust possession of revenue owed to the business owner qua capital producer and to labor qua supplier of surplus value.

Two other points need to be made. Since capital gets globalized at the national level, such private enrichment harms the national interest as evidenced by the economic damage to innocent depositors caused by US banks and financial institutions when they engaged in the production of fictitious surplus value. Furthermore, insofar as we are now in a transitional phase in which private production through the abuse of social capital remains a perennial problem, the business-ethics-oriented study of whose interest companies should actually serve remains highly relevant. We clearly need to place greater emphasis on making banks and financial institutions manage social capital in the interest of society. The need to prevent public servants from becoming social masters was an issue raised by Karl Marx in his book The Civil War in France (Marx 1972, pp 334-335). This problem plagues not only government officials and managers of state-owned enterprises within socialist countries, but also businesses, especially banks and credit institutions, within capitalist countries.

Managers of banks and credit institutions should not only be supervised. Because they play such a crucial role in the management of credit economy, they must take on the responsibility implicit in this economy. They should be enhancing industrial capital by putting social capital into the hands of those who know how to maximize this capital's utility. They should not be engaged in the worldwide production of fictitious surplus value, a form of mismanagement that plunders social capital. As a spokesperson for the Auditor's Office of New York state put it, the incentive mechanism for investment banks has been the costs generated by their portfolio of financial products rather than the actual long-term performance and profits of these products. Brokers of mortgage-backed loans and Wall Street risk managers had no idea of how investment works. They considered only short-term gains and cared not one whit about the long-term health of companies (New York Times 2008). 
Governments are responsible for supervising banks and credit institutions. Much could be said about this responsibility, but I wish to stress one point: The government should strive to foresee how its policy will likely impact society. Take the AMPTA passed in 1982 by the US Congress. This law allowed eligible nongovernmental housing creditors to adopt ARMs (which later surfaced in some predatory loans). In 1995, the US tax policy encouraged Fannie Mae and Freddie Mae to buy MBSs, including ones built upon subprime mortgages. Then, in 1996, the US Department of Housing and Urban Development stipulated that a minimum of $42 \%$ of the subprime mortgage loans (to be bought by Fannie Mae and Freddie Mac) should be granted to households with incomes lower than the regional median. This target was raised to 50\% in 2000 and 52\% in 2005 (New York Times 2008). These imperatives and practices were later misused, in part because the US government lacked foresight and took no action against fraudsters.

Greenspan preferred that the market take care of the mess. But such a policy prevents the government from playing a crucial role in minimizing the damage. Here in China, the government has played a more prominent role; the market functions only as a partial remedy. Yet China's expanding real estate bubble suggests that China, too, is experiencing private production without the control of private property. Some banking managers, property developers and local government officials have focused more on personal rewards, profits, and political performance than on the interest and safety of social capital and public assets. As a result, the housing market bubble keeps expanding. This last remark brings me to the topic of social responsibility. To make social capital produce for society rather than for individuals, stakeholders of social capital must play their part. Society has the duty to make social capital produce for society. From the perspectives of stakeholder theory, corporate governance, and corporate social responsibility, users and producers of social capital have an ethical duty to act in the interest of both the social capital's owners and society as a whole. This latest financial crisis teaches us that we ought to ponder Marx's arguments concerning the transitional phase. It teaches us as well that the theory and practice of business ethics needs to explore how to maximize and promote social interests within the domain of capitalist production mode. Such a focus is our best hope to avoid another massive financial disaster.

Acknowledgment The author would like to thank Prof. Daryl Koehn for editing the manuscript in English.

\section{References}

Associated Press (2007). "Will the subprime mess ripple through economy?" March 13. Available at: http://www.msnbc.msn.com/id/17584725.

BBC NEWS (2007) The US sub-prime mortgage crisis has led to plunging property prices, a slowdown in the US economy, and billions in losses by banks. It stems from a fundamental change in the way mortgages are funded. Available at: http://news.bbc.co.uk/2/hi/business/7073131.stm.

Beams, Nick (2008). "The world economic crisis: a Marxist analysis". Available at: http://www.wsws.org/ articles/2008/dec2008/nbe5-d24.shtml.

Bernanke, Ben, S. (2007). "The subprime mortgage market," Chicago, Illinois, May 17. Available at: http://www.federalreserve.gov/printable.htm. 
Bernanke, Ben, S. (2007)."Chairman Ben S. Bernanke at the Bundesbank Lecture,” Berlin, Germany, September 11. Available at: http://www.federalreserve.gov/newsevents/speech/bernanke20070911a.htm.

Brooks, Rick, and Simon, Ruth (2007). "Subprime debacle traps, even very credit-worthy," The Wall Street Journal Online, December 04.

Dodd, Chris (2007). "Senator Dodd: create, sustain, preserve, and protect the American dream of home ownership", US Fed News, Feburary 7. Available at: http://dodd.senate.gov/?q=node/3731.

Knox, Noelle (2006). "43\% of first-time home buyers put no money down," USA TODAY, July, 18.

Marx, K. (1972). "The civil war in France”, selected works of Marx and Engles (Vol. 2). Beijing: People's Publishing House.

Marx, K. (2004). Capital (Vol. 1-3). Beijing: People's Publishing House.

Michalos, A. C. (1997). Good taxes. Toronto: Dundurn Press.

Michalos, A. C. (2000). A handful of sand in the wheels of financial speculation. In B. K. Maclean (Ed.), Out of control: Canada in an unstable financial world (pp. 145-159). Ottawa: Canadian Centre for Policy Alternatives and James Lorimer and Co.

New York Times (2008). Available at: http://www.nytimes.com/2008/12/18/business/18pay.html?em.

Pittman, Mark, and Ivry, Bob (2008). "U.S. Pledges Top \$7.7 Trillion to Ease Frozen Credit (Update3)," November 24, Bloomberg News. Available at: http://www.bloomberg.com/apps/news?pid=newsarchive\& $\mathrm{sid}=\mathrm{a} 5 \mathrm{PxZ} 0 \mathrm{NcDI} 4 \mathrm{o}$.

Reuters (2009). "G20 Declares Victory over Crisis," Pittsburg, September 25.

Rose, Charlice (2009). “A conversation with Jeff Immelt, Chairman and CEO of GE,” Business, June 25. Available at: http://www.charlierose.com/view/interview/10412.

Song, Hongbing (Ed.), (2009). Currency War II: The World of Financial Powers. b Chinese Beijing: Chamber of Commerce and Industry Publishing House.

The Economist (2007). "A survey of the world economy. Assets and their liabilities. The case for tackling asset prices - and the difficulties of pulling it off," Oct 18th 2007. Available at: http://www.economist. com/specialreports/displaystory.cfm?story_id=9972549.

The Federal Reserve Board (2010) "Intended federal funds rate Change and level, 1990 to present." Available at: http://www.federalreserve.gov/fomc/fundsrate.htm.

The Financial Crisis Inquiry Commission (FCIC) (2011). The financial crisis inquiry report-final report of the national commission on the causes of the financial and economic crisis in the United States. Janury, Official Government Edition.

This American Life (2008). "The giant pool of money." Available at: http://www.thisamericanlife.org/ Radio_Episode.aspx? episode $=355$.

Wikipedia, the free encyclopedia. "Subprime mortgage crisis". Available at: http://en.wikipedia.org/wiki/ Subprime_mortgage_crisis

Zakaria, Fareed (2008). “A more disciplined America,” Newsweek, October 11. 